\title{
Rock control on microweathering of bedrock surfaces in a periglacial environment
}

\author{
Dawn T. Nicholson* \\ Department of Environmental and Geographical Sciences, Manchester Metropolitan \\ University, Chester Street, Manchester, M1 5GD, United Kingdom \\ *Tel.: +44 (0)161 247 6232; E-mail: d.nicholson@mmu.ac.uk.
}

\begin{abstract}
Microweathering of ice-smoothed bedrock surfaces was investigated in the Røldal area of Hardanger Plateau $\left(60^{\circ}\right)$, southern Norway. Postglacial rates of weathering were determined from surface lowering using quartz veins as reference surfaces. Weathering processes are inferred from assessment of weathering rind formation, surface hardness, and the preservation of small-scale glacial erosional features.
\end{abstract}

Surface lowering rates for a range of metamorphic rocks vary from 0.05 to $2.20 \mathrm{~mm}$ $\mathrm{ka}^{-1}$ and are broadly comparable with those obtained from crystalline rocks in other periglacial environments. The mean rate of surface lowering at $0.55 \mathrm{~mm} \mathrm{ka}^{-1}$ is low and demonstrates the relatively small impact of microweathering on postglacial landscape evolution. Variations in bedrock microweathering can be explained by lithological variation. Amphibolite and mica-rich bedrock surfaces experience greater denudation and weakening, least weathering rind formation, and abundant preservation of glacial striae, despite greater surface lowering. Conversely, quartzrich bedrock surfaces are most resistant to denudation and weakening, but have greater weathering rind formation and fewer preserved striae. Postglacial microweathering is achieved primarily through granular disintegration involving detachment and removal of mineral grains and weakening from increased porosity. Granular decomposition is manifest in the formation of weathering rinds. Analysis of interactions between weathering indices indicates that rind accumulation is limited by microerosion.

A conceptual model is proposed that illustrates the temporal interrelationships between in situ and erosional facets of microweathering in two contrasting mineral assemblages. The model proposes that cyclic processes of in situ disintegration, decomposition, and erosion are at work. The relative balance between these processes varies with lithology so that in more resistant quartz-rich rocks the net effect is minimal surface lowering and accumulation of weathering rind. In weaker, amphibolitic and micaceous rocks, the net effect is greater surface lowering and minimal accumulation of weathering rind. The results of the research demonstrate the important influence of rock properties, notably mineral composition, in postglacial microweathering of crystalline bedrock in a periglacial environment.

Keywords: rock control; weathering; bedrock; periglacial; surface lowering; weathering rind 


\section{Introduction}

Since Yatsu (1966) advocated greater attention to rock control in geomorphology, a call he later reiterated specifically in relation to weathering (Yatsu, 1988), many studies have explored the interrelationships between rock properties, breakdown rates, and landform evolution. Earlier work is reviewed by Matsukura (1994), but examples include the determination of bedrock weathering rates using reference features (Dahl, 1967; André, 2002; Owen et al., 2006) and the role of intrinsic rock properties in microweathering processes (e.g., Matsuoka et al., 2006). The latter include investigations of weathering rind formation (e.g., Chinn, 1981; Colman and Pierce, 1981; Etienne, 2002) and the influence of lithological and structural properties on landform evolution (e.g., Tuğrul, 1997; Glasser et al., 1998; Olvmo and Johansson, 2002). External controls on bedrock weathering processes have also been examined (e.g., Hall et al., 2002) including the role of thermal stresses (e.g., Hall, 1999; Hall and André, 2001) and enhanced weathering associated with latelying snowpatches (e.g., Thorn, 1975; Ballantyne et al., 1989; Berrisford, 1991; Nyberg, 1991). An understanding of microweathering processes and their effect on rock properties has also been used to aid interpretation of mass movement (Selby, 1980; Douglas et al., 1991) and to reconstruct Quaternary environments (e.g., Ives, 1966; Ballantyne et al., 1998; Sumner et al., 2002; Rae et al., 2004). Nevertheless, few studies have been conducted of postglacial microweathering of crystalline rocks in active periglacial environments. Also, few examples exist of studies that have taken a multiple weathering index approach to provide a more holistic evaluation of process-lithology-environment interactions, though such studies are increasing (e.g., Rae et al., 2004; Matsuoka et al., 2006).

Studies have suggested that postglacial rates of microweathering on crystalline bedrock are low (Dahl, 1967; André, 2002), but that lithological controls can explain much of the variability in weathering rates (André, 2002; Matsuoka et al., 2006) and surface wear characteristics (Thorp, 1981; Glasser et al., 1998). However, gaps remain in our understanding of the extent to which bedrock lithology has affected rates and processes of microweathering during the postglacial period. For example, to what extent is it possible to link susceptibility to postglacial bedrock microweathering to particular mineral assemblages? Is it possible to identify any patterns in the nature of microweathering (e.g., through surface weakening or in situ rind formation) in relation to rock type and mineral composition? What are the temporal patterns of microweathering during the postglacial period?

This paper presents the findings of a study of rock control on microweathering rates and processes on ice-scoured crystalline bedrock surfaces in an active periglacial environment. The objectives of the research were to (i) determine postglacial weathering rates from bedrock surface lowering for contrasting crystalline rocks and make comparisons with rates obtained from elsewhere; (ii) evaluate the influence of lithology on microweathering; (iii) assess the interactions between surface lowering, weathering rind formation, and surface hardness for contrasting rock types; and (iv) make inferences about microweathering processes and their role in the evolution of cold environment landscapes. 


\section{Study area}

The study area is situated in the vicinity of Røldal in southern Norway at around $6^{\circ} 58^{\prime}$ E. and $59^{\circ} 53^{\prime} \mathrm{N}$., on Hardangervidda, the largest high mountain plateau in Europe.

\subsection{Geomorphic environment}

Hardangervidda generally has subdued relief with tundra vegetation. However, the southwestern portion that is the subject of this study has been partially dissected and includes deep valleys, locally steep slopes, and widespread ice-moulded bare rock surfaces (Fig. 1). Many of these surfaces display the characteristic form of roches moutonnées, but many are whalebacks with no distinctive asymmetry in long profile. Erratics and limited remnants of till lie on top of some of the roches moutonnées, and numerous surfaces display glacial erosional features such as striae, grooves, and Pforms.

Forty-five roche moutonnée and whalebacks were selected for investigation at five localities in the Røldal area; Rekkingeskara $\left(1.5 \mathrm{~km}^{2}\right)$, Snøskar $\left(3 \mathrm{~km}^{2}\right)$, Middyrelva $\left(1500 \mathrm{~m}^{2}\right)$, Dyrskarnuten $\left(1500 \mathrm{~m}^{2}\right)$, and Fjetlandsnuten $\left(2000 \mathrm{~m}^{2}\right)$; totalling $4.5 \mathrm{~km}^{2}$ (Fig. 2). The altitude of study sites ranges from 950 to $1520 \mathrm{~m}$, mean annual temperature for the area is $-2^{\circ} \mathrm{C}$, and mean annual precipitation is $1525 \mathrm{~mm}$. Permanent and semipermanent snowpatches are common in the area, and glaciers lie only 5 to $10 \mathrm{~km}$ to the east at an altitude of c. $1600 \mathrm{~m}$. Although there are some semipermanent snowpatches near to most of the study sites, the bedrock surfaces investigated are normally free of snow in mid-summer, except after winters of exceptional snowfall. However, most of the study sites are buried in snow until at least late spring, and many snowpatches persist to early summer in years with "normal" winter snowfall and summer temperatures.

All of the study sites lie above the upper limit of boreal forest and support high alpine tundra with little vegetation, dominated by bare bedrock with sediment and boulderladen surfaces in between (Fig. 3). Bedrock surfaces are commonly colonised by crustose lichens, including Rhizocarpon geographicum. Sphagnum moss is ubiquitous, and some ericaceous heath is found with Vaccinium species and Empetrum, as well as some coarse tussock grasses and sedges. In some sheltered locations, Salix arctica (rock willow), Rubus chamaemorus (cloudberry), and Vaccinium spp (blueberry) colonise. Generally, soil development is absent or incipient, dominated by local accumulations of grus and glacially derived silt.

The Røldal sector of Hardangervidda is dominated by upstanding roches moutonnées and whalebacks interspersed with lakes and pools and sometimes surrounded by blockstreams. Solifluction activity, ploughing boulders, and patterned ground are also present. Occasionally, till-covered basins support moderate ericaceous heath and fingers of vegetation spread up the lower slopes of roches moutonnées. Sometimes, soil lies within weathering pits on the roche moutonnée crests. 


\subsection{Geology}

Some understanding of the regional geology was obtained from the 1:50 000 bedrock geology maps 1414 IV and 1314 I produced by the Norges Geologiske Unders $\varnothing$ kelse (Jorde, 1977; Naterstad, 1988). However, local field mapping and thin section analysis were conducted to obtain site specific lithological information. Most of the study area (notably Rekkingeskara and Snøskar) is located in crystalline rocks of the Precambrian basement, heavily deformed by Nappe complexes of Proterozoic age, although significant variability in mineral composition and metamorphic fabric exists. The Stavsnuten Nappe complex consists mainly of granitic gneiss and mica schist, particularly quartzitic and quartzo-feldspathic schist. Limited outcrops of biotite amphibolite are also present. The lower grade Dyrskardnuten Nappe complex consists mainly of hornblende-amphibolite schist with some quartzite. At Fjetlandsnuten the bedrock comprises Precambrian autochthonous rocks consisting of actinolite-amphibolite gneiss, probably derived from metamorphosed basalt. At Middyrelva, bedrock lithology is from the Mannevatn Nappe in Ordovician metasediment, generally consisting of chlorite-rich mica schist and phyllite with numerous quartz veins.

Petrological analysis reveals that four distinctive lithological groups can be recognised, relating to the percentage of pale minerals present (particularly quartz and feldspar) and the proportion of amphibolite: Hololeucocratic rocks contain $<10 \%$ mafic minerals and are composed primarily from quartz, often also with significant microcline and other feldspars. Muscovite micas sometimes comprise $25 \%$ of the minerals present. Common accessory minerals include opaques and biotite. This group is characterised by quartzite, muscovite micaschist, and quartzo-feldspathic schist. Leucocratic rocks contain $10-35 \%$ mafic minerals and have a similar general composition to hololeucocratic rocks, but usually with a smaller proportion of quartz and more feldspar. Biotite occurs with slightly greater frequency, but other accessory minerals are also important, including epidote, sphene, and chlorite. This group is characterised by feldspathic gneiss, chlorite mica schist, and biotite-epidote schist. Mesocratic rocks contain 35-65\% mafic minerals and are composed mainly from quartz, plagioclase feldspar, and biotite in approximately equal proportions. Common accessory minerals include epidote, sericite micas, and apatite. This group is characterised by biotite gneiss. Amphibolitic rocks contain $35-90 \%$ (typically $50-60 \%$ ) amphibole (usually hornblende, but also actinolite) with plagioclase feldspar and little quartz present. Common accessory minerals include epidote, opaques, biotite, and chlorite. These rocks include all forms of amphibolite including amphibolite gneiss, hornblende-chlorite schist, biotite amphibolite, and actinolite amphibolitic gneiss. Using the same criteria as for the previous rock groups, most of these amphibolites are melanocratic, comprising $>65 \%$ mafic minerals.

\section{Methods}

Four methods were used to characterise microweathering rates and processes on a total of 45 roches moutonnées or whalebacks at the five sites. Most sampling took place at Rekkingeskara (22) and Snøskar (15), with additional data from Middyrelva (2), Fjetlandsnuten (3), and Dyrskarnuten (3). Roches moutonnées were selected primarily to ensure good coverage of the major lithological types. However, spatial coverage and degree of exposure were also important considerations in selection. 


\subsection{Bedrock surface lowering}

Bedrock surface lowering was determined using upstanding quartz veins as reference surfaces, following the method established by Dahl (1967). Resistant to weathering, these polished quartz veins represent the preweathered, ice-scoured surface at the end of the Younger Dryas. Height differences were obtained to the nearest $0.1 \mathrm{~mm}$ using a calliper and for a given vein, measurements were made on both sides at $1 \mathrm{~cm}$ intervals. Up to 50 measurements were taken from each vein, and up to three veins studied per roche moutonnée. Guidance by Dahl (1967) on the selection of suitable veins for measurement was followed. Surface lowering rates should be regarded as minimum rates because some vein surfaces exhibited minor degradation. Over 1000 measurements were made at 23 sites.

A chronological constraint of 10000 years BP was used to determine postglacial rates of bedrock surface lowering based on events at the end of the Younger Dryas. Norway is believed to have been rapidly deglaciated by about $9000{ }^{14} \mathrm{C}$ years with the last remnants of ice disappearing from higher ground such as Hardangervidda by $8500{ }^{14} \mathrm{C}$ years (Anderson, 1980). Therefore, bedrock in the Røldal area would have been exposed to atmospheric weathering at $8750 \pm 250{ }^{14} \mathrm{C}$ years, equivalent to c. 10 000 years BP (Stuiver et al., 1998). Some caution is necessary in interpreting postglacial weathering rates as a single date of exposure masks climatic fluctuations during the Holocene and short term variation in late-lying snow cover.

\subsection{Weathering rind thickness}

The thickness of bedrock weathering rind provides a useful indicator for the time of exposure to weathering processes, weathering intensity and susceptibility to weathering (e.g., Thorn, 1975; Chinn, 1981; Dixon et al., 2002; Sumner et al., 2002). For each roche moutonnée, weathering rind thickness (WRT) was obtained for exposed bedrock surfaces and fracture walls. Surface WRT was obtained from 25 $\mathrm{mm}$ diameter drilled cores sampled from the smooth crests of roches moutonnées. Fracture wall WRT was obtained from rock specimens obtained from the intersections of closed fractures or joints using a geological hammer. Values of WRT were determined to the nearest $0.2 \mathrm{~mm}$ with the rind boundary identified primarily from colour change. For each roche moutonnée, 15 to 20 measurements were made, with a total sample number of 669 measurements (527 of surface rind and 142 of fracture wall rind). These data represent the mean maximum WRT for each roche moutonnée as recommended by Thorn (1975).

\subsection{Bedrock surface hardness}

A calibrated "N" type Schmidt hammer was used to determine bedrock surface hardness. A review of the instrument and its use in geomorphological investigation is provided by Goudie (2006), and a fuller account of the method used in this study is given by Nicholson (in review). For each roche moutonnée, values were obtained for 25 pairs of impacts, with the two impacts for each pair being made at a single point. This approach provides the first rebound value $\left(R_{1}\right)$, representing the hardness of the weathered surface, and the second rebound value $\left(R_{2}\right)$, more closely approximating intact rock strength. Comparison of $R_{1}$ and $R_{2}$ provides an index of surface 
weakening due to weathering. More than 2000 values were obtained, and all have been adjusted for angle with respect to a horizontal surface (Day and Goudie, 1977).

\subsection{Morphometry of glacial striae and grooves}

Striation morphometry was determined to quantify and verify an apparent dichotomy observed during an early field visit that striae and grooves appeared to be more abundant on bedrock that had experienced the greatest postglacial surface lowering. Several examples are cited in the published literature where preserved striae have been used to assist in the interpretation of weathering in relation to lithological controls. For example, Glasser et al. (1998) noted that fewer striae and grooves were preserved on strongly foliated schists compared with more homogenous marble and concluded that surface wear characteristics were a function of the penetration hardness of the bedrock. For Dalradian metamorphic and igneous rocks, Thorp (1981) noted that spatial variability of small-scale erosional forms, such as crescentic gouges and striae, were related to lithology. Working on ortho-gneiss and augengranite, Olvmo and Johansson (2002) found a significant difference in surface "etching" by glacial erosion on the two lithologies. In this study, morphometric data were obtained to quantify the preservation of microerosion forms in relation to rock type. At each site where striae and grooves were found, mean width $( \pm 0.5 \mathrm{~mm})$ and depth $( \pm 0.25 \mathrm{~mm}$ ) were recorded up to a maximum of 45 data on a single roche moutonnée. A total of 380 measurement sets were obtained.

\section{Results}

\subsection{Rates of bedrock weathering}

\subsubsection{Postglacial bedrock surface lowering}

Using 10000 years BP as the reference point for bedrock exposure, the overall mean rate of postglacial lowering as determined from the measurement of quartz vein reference surfaces is $0.55 \mathrm{~mm} \mathrm{ka}{ }^{-1}$, and mean values for roches moutonnées of different rock types range from 0.25 to $0.89 \mathrm{~mm} \mathrm{ka}^{-1}$ (Table 1). Rates of surface lowering are comparable with those determined for a similar range of rocks in northern Sweden (André, 1995, 1996a, b, 2002) and northern Norway (Dahl, 1967). André (2002) also reported comparable rates obtained by others working in lowland Canada (0.5-1.2 $\mathrm{mm} \mathrm{ka}^{-1}$ for metamorphic rocks) and temperate Sweden $\left(1.5 \mathrm{~mm} \mathrm{ka}{ }^{-}\right.$ ${ }^{1}$ for gneiss and mica schist). Measurements of surface lowering can be converted into denudation rates to enable comparison with chemical erosion rates derived from analyses of solute loads. Using the overall mean surface lowering rate of $0.55 \mathrm{~mm}$ $\mathrm{ka}^{-1}$ and assuming an average rock density of $2650 \mathrm{~kg} / \mathrm{m}^{3}$, surface lowering equates to the removal of $1.5 \mathrm{t} \mathrm{km}^{-2} \mathrm{a}^{-1}$ of material from the Røldal area. The rate based on the maximum surface lowering value obtained $\left(2.20 \mathrm{~mm} \mathrm{ka}^{-1}\right)$ is $5.8 \mathrm{t} \mathrm{km}^{-2} \mathrm{a}^{-1}$. Comparison of denudation rates derived from bedrock surface lowering and solute load (Table 2) usefully demonstrates that rates for the Røldal area are low, but of the same order of magnitude as those obtained for Latnjavagge $\left(5.4 \mathrm{t} \mathrm{km}^{-2} \mathrm{a}^{-1}\right)$ in Swedish Lapland (Beylich et al., 2004) (although such comparisons must be taken with caution as the rates derived from solute load include chemical weathering of surficial deposits). André suggested (1995) that the similarity in surface lowering rates across a broad range of environmental conditions was evidence that azonal 
biological agents were at work. However, given the similarity in metamorphic bedrock types across these different studies, azonal processes may also point to the controlling influence of rock properties.

Overall, these data show a trend for greater surface lowering of rocks containing higher proportions of mafic and amphibolitic minerals (Fig. 4). Surface lowering rates for the hololeucocratic and leucocratic rocks are 0.48 and $0.44 \mathrm{~mm} \mathrm{ka}^{-1}$, respectively, and total postglacial surface lowering is c. $4.6 \mathrm{~mm}$. Surface lowering rates for the mesocratic and amphibolitic rocks are 0.61 and $0.68 \mathrm{~mm} \mathrm{ka}^{-1}$, respectively, and total postglacial surface lowering is c. $6.7 \mathrm{~mm}$. One-way analysis of variance (KruskalWallis) indicates that there is an overall significant difference between surface lowering in the four rock groups $(H=101.07, \mathrm{df}=3, P<0.01)$. Dunn's multiple comparison test showed a significant difference in surface lowering between each of the rock groups, except for the mesocratic and amphibolitic rocks (Fig. 5).

\subsubsection{Glacial erosion of bedrock surfaces}

Many fewer striae were preserved $(n=63)$ in quartz and feldspar-rich rocks compared with more mafic and amphibolitic rocks $(n=310)$. No significant difference in striae width and depth exists between the rock groups although analysis of median values indicates a tendency for hololeucocratic and leucocratic rocks to be narrower and shallower than overall median values (Table 3). Grooves (> $100 \mathrm{~mm}$ wide) were found in all rock types, and surface lowering will have had little effect on their preservation. The finest striae ( $<5 \mathrm{~mm}$ wide) were generally only preserved under soil or sediment cover or on exposed bedrock where there was clear evidence (an absence of lichen) of frequent, late-lying snow cover.

\subsection{In situ modification of bedrock}

\subsubsection{Surface hardness}

Schmidt hammer rebound gave overall mean values for $R_{1}$ and $R_{2}$, respectively, of 54 and 64 . The mean $R_{1}$ values for the four rock groups were $59.8,57.1,50.9$, and 46.0 , respectively, and for $R_{2}$ were $67.8,65.8,62.0$, and 59.7 (Table 4). These data indicate a clear trend for decreasing hardness with increasing mafic and amphibolitic minerals (Fig. 6). One-way analysis of variance (Kruskal-Wallis) indicates that there is an overall significant difference between surface hardness in the four rock groups $(H=292.51, \mathrm{df}=3, P<0.01)$. Dunn's multiple comparison test showed a significant difference in $R_{1}$ between each of the rock groups, and in $R_{2}$ between each of the rock groups except for the mesocratic and amphibolitic rocks. Values for surface hardness are comparable with those obtained for similar bedrock in other regions (Goudie, 2006), though a little higher than for other metamorphic rocks reported and more akin to igneous rocks such as granite and gabbro. This may reflect the relatively fresh nature of these glacially eroded rocks as they were not exposed until the end of the Younger Dryas. A highly significant correlation exists between $R_{1}$ and $R_{2}(r=0.93$, df $=33, P<0.01)$ and rebound values show a significant increase for the second measurement $R_{2}(t=15.39, \mathrm{df}=37, P<0.01)$. This is evidence that weakening of the surface has taken place from weathering. 


\subsubsection{In situ weathering rind}

The mean maximum thickness of weathering rind for exposed surfaces was $3.3 \mathrm{~mm}$ (Table 5). Mean surface WRT for the four rock groups were $5.0 \mathrm{~mm}, 3.3 \mathrm{~mm}, 1.9$ $\mathrm{mm}$, and $2.4 \mathrm{~mm}$, respectively. These data show a trend for increasing WRT in quartz-rich rocks with the thinnest rinds occurring in amphibolite (Fig. 7). One-way analysis of variance (Kruskal-Wallis) indicates that there is an overall significant difference between surface WRT in the four rock groups $(H=15.92$, $\mathrm{df}=3, P<0.01)$. Dunn's multiple comparison test showed a significant difference between the hololeucocratic and amphibolitic rocks. The rind thicknesses obtained are comparable with those obtained for a range of igneous rocks including 1.0 to $6.4 \mathrm{~mm}$ in quartz-porphyry (Oguchi et al., 2001), 0.8 to $2.3 \mathrm{~mm}$ postglacial development in andesite (Aoyama, 2005), 0.5 to $1.4 \mathrm{~mm}$ in syenite (Thorn, 1975), and up to $3.8 \mathrm{~mm}$ in very recently exposed basalt (Etienne, 2002).

The mean maximum thickness of weathering rind on fracture walls was $2.5 \mathrm{~mm}$ (Table 5). These data show a trend for increasing weathering rind thickness in quartz-rich rocks with the thinnest rinds again occurring in the amphibolites (Fig. 8). One-way analysis of variance (Kruskal-Wallis) indicates that there is an overall significant difference between fracture WRT in the four rock groups $(H=14.86, \mathrm{df}=$ $3, P<0.01)$. Dunn's multiple comparison test showed a significant difference between the hololeucocratic rocks and the other three rock groups.

One-way analysis of variance using the Z-test (Kolmogorov-Smirnov) indicates that across all rock types, there is a highly significant difference between WRT obtained from bedrock surfaces and from fracture walls $(Z=2.66, \mathrm{df}=\infty, P<0.001)$.

\section{Rock control on weathering rates and processes}

\subsection{Rock control on denudation rates}

Analysis of denudation rates in different rock groups reveals that the greatest resistance to surface lowering occurs in rocks with a high proportion of quartz and least resistance occurs in rocks with a high proportion of amphibolite. Chlorite, sericite, and muscovite micas also coincide with elevated rates of surface lowering, even when a moderate proportion of quartz is present. André (2002), working in the Abisko-Riksgränsen region, found amphibolites to be among the most resistant rocks. However the northern Scandinavian amphibolites were quartz-rich, being classified by André as leucocratic, whereas most of the amphibolites in this study are melanocratic, having 65-90\% mafic minerals. André (1995), working on granites, also found biotite-rich bedrock to be highly susceptible to surface lowering. In the Røldal area, some mesocratic rocks containing $25-30 \%$ biotite, show moderately high susceptibility to microweathering. However, one roche moutonnée $(P)$, consisting of $15 \%$ biotite and $60 \%$ quartz, shows one of the lowest surface lowering rates obtained in this study. This probably indicates that the presence of a significant proportion of quartz overrides the potential response to microweathering of biotite and other mafic minerals.

Ironically, the most surface lowering found in this study occurs in hololeucocratic bedrock on a roche moutonnée $(E)$ at Snøskar, which at $1488 \mathrm{~m}$, is at the highest 
elevation of all of the localities investigated. Deglaciation at the end of the Younger Dryas would have occurred first at higher elevations. Therefore, localities such as this will have had the greatest opportunity for surface lowering by microweathering.

It is apparently contradictory that glacial striae were preserved most abundantly on amphibolite bedrock that has undergone the most surface lowering. An obvious explanation would be to suggest that upstanding quartz veins and striae simply do not occur at the same locality. In other words, striae are preserved preferentially where they have been protected, by overlying soil or sediment cover, for instance, and surface lowering has not taken place in that precise location. However, while it is true that some fine striae were observed beneath shallow sediment cover, striae were also observed in very close proximity to upstanding quartz veins, and in fact, the two features actually intersected each other at two localities. This suggests that the original striae in the amphibolites were sufficiently deep and wide that they have been preserved despite surface lowering. Conversely, in the quartz-rich rocks, either many fewer striae were abraded into bedrock surfaces, or original striae were very fine, and have not been preserved, despite minimal surface lowering. The former makes sense as these rocks are tough and would not have been so readily abraded, a contention that concurs with the findings of Glasser et al. (1998).

\subsection{Rock control on microweathering processes}

The occurrence of surface lowering, weathering rind formation, and surface weakening in the Røldal area indicate that microweathering is achieved through a combination of granular disintegration and decomposition. The presence of weathering rind is evidence for the alteration and dissolution of minerals. Qualitative analysis of dye-injected petrological samples from the Røldal area provides evidence for increasing porosity at the bedrock surface, achieved through intergrain and grain boundary dissolution and microcracking. Increased porosity provides one mechanism for surface weakening, as reflected in $R_{1}$ values, and is also associated with rind formation (Oguchi and Matsukura, 2000). Surface lowering is achieved, in part, through the physical detachment and removal of mineral flakes (notably feldspars and micas), and may be associated with lichen penetration (e.g., André, 1995; Chen et al., 2000). Factors promoting granular breakdown are speculative here, but include external stresses from thermal fluctuations (e.g., McGreevy, 1985; Hall, 1999; Hall and André, 2001), chemical and biochemical processes (e.g., Etienne and Dupont, 2002; Carter and Viles, 2004; Dixon and Thorn, 2005), and the presence of intrinsic weaknesses such as rock flaws (e.g., Nicholson and Nicholson, 2000).

Weathering rind is ubiquitous on bedrock surfaces in the Røldal area, although its thickness varies. Increasing evidence suggests that rind formation is strongly dependent upon moisture availability (Etienne, 2002) and associated with an increase in porosity (Dixon et al., 2006). The latter is thought to result from intergrain dissolution and the formation of microcracks associated with biochemical activity, particularly in feldspar and quartz (Dixon et al., 2006). This concurs with the finding in the Røldal area that weathering rind is thickest in the quartzo-feldspathic rocks.

The relationship between weathering rind thickness and rock surface hardness is worthy of consideration. Several authors have noted the importance of microerosion in the formation and cycling of weathering rind (Etienne, 2002; Gordon and Dorn, 
2005; Nicholson, in review). It is highly probable that susceptibility of rind to microerosion is related to rock surface hardness, particularly as the latter is partially dependent upon rock porosity (e.g., Nicholson, 2001). However, the relationship between the two indices is not straightforward. In this study, the thickest rinds were found on the strongest bedrock. The coincidence of greater porosity with rind formation in other studies would lead to one to expect the opposite (i.e., that thicker rinds would be found on weaker bedrock). However, in weaker rocks or rocks with relatively higher porosity, the rate of rind formation may be outpaced by rind removal from microerosion, thus giving the false impression that there is little primary rind development.

This study provides quantifiable evidence of rock control on rates and processes of bedrock microweathering. The fact that rates are comparable with those from widely different environments suggests azonal processes are in operation (André, 2002) and that environmental and climatic conditions are subservient to lithological and/or biotic influences. However, there are exceptions to this; the high elevation roche moutonnée previously referred to perhaps displays greater surface lowering because of an extended period of exposure since deglaciation. This concurs with the expectation of greater intensity of weathering at nunatak localities (e.g., Rae et al., 2004). It is also in accord with the much greater density of lichen cover at higher elevations, a condition linked with greater intensity of weathering (Chen et al., 2000). If this observation is correct, this points to environmental control being dominant over rock control in some cases. However, the role of environmental and climatic influences is complex. At lower elevations, for instance, where bedrock surfaces experience much longer duration of snow cover, enhanced weathering may occur in response to the particular micro-environmental conditions prevailing (e.g., Gardner, 1969; Thorn, 1975; Ballantyne et al., 1989; Berrisford, 1991; Thorn and Hall, 2002).

\section{A temporal-lithological model of bedrock microweathering}

The data presented for bedrock surface lowering, weathering rind thickness, surface hardness, and the preservation of small-scale glacial erosional forms shows a clear pattern in microweathering rates and processes across different groups of rocks (Fig. 9). This pattern indicates that mineral composition is of fundamental importance in determining weathering susceptibility. A conceptual model is proposed of the response to bedrock microweathering during the postglacial period of two contrasting lithological assemblages.

\subsection{Amphibolites and micaceous bedrock (Fig. 10A)}

During the last glaciation in the region, the relatively soft amphibolites would have been readily abraded by glacial debris. Immediately following recession of the ice sheet, ice-scoured surfaces would have been exposed, displaying abundant striae and grooves of all sizes (phase I). Because of their inherent lack of strength, bedrock surfaces would have quickly become weakened, manifest through increased porosity, grain boundary dissolution, and microcracking at and near to the surface, accompanied by in situ development of weathering rind (phase II). However, as the zone of weakening deepened, microerosion through detachment and removal of mineral flakes occurred, lowering the bedrock surface and reducing the thickness of weathering rind (phase III). This measurable lowering of the surface probably led to 
the disappearance of some very fine striae (except where they were protected beneath soil or sediment cover), but many were preserved. As this cyclic process of bedrock surface microweathering continued to the present day, rind growth must have occurred at a rate marginally faster than surface lowering, allowing it to thicken, albeit at a slow rate (phase IV). This is, in effect, a system in which accumulation of rind is limited by surface microerosion. Because of continued surface lowering, striae shrink further, but many are still well preserved.

\subsection{Quartz-rich bedrock (Fig. 10B)}

During the last glaciation in the region, the relatively hard quartz-rich bedrock would have been resistant to abrasion by glacial debris. Immediately following recession of the ice sheet, ice-scoured surfaces produced by macroerosion would have been exposed, displaying occasional striae and large grooves (phase I). Because of their inherent strength, bedrock surfaces would have been slow to weaken. Nevertheless, some increase in porosity, grain boundary dissolution, and microcracking at and near the surface would have been accompanied by in situ development of weathering rind (phase II). The zone of weakening would have deepened, but slowly, through detachment and removal of mineral flakes leading to minor surface lowering and a small reduction in thickness of the weathering rind (phase III). This slow rate of surface lowering would have allowed continued thickening of the rind and would have preserved a high proportion of the original striae, albeit they were few. Any very fine striae would have been removed. As this cyclic process of bedrock surface microweathering continued to the present day, rind growth must have occurred significantly more rapidly than surface lowering (phase IV). This is, in effect, a system in which accumulation of rind is permitted by the relative lack of surface microerosion. Because of slow, but continued surface lowering, most of the original striae disappear and only the larger striae and grooves remain.

Etienne (2002) showed that weathering rinds of up to $3.8 \mathrm{~mm}$ thick developed on basalts exposed for only 110 years, demonstrating that very rapid rind growth is possible in some situations. Given that the bedrock surfaces investigated in the Røldal area are thought to have been exposed for c. 10000 years, substantial rind growth could theoretically occur. However, the maximum theoretical rind thickness is constrained by the presence of quartz veins as reference surfaces which indicate the position of the bedrock surface at the end of the Younger Dryas. Assuming that all of the material that has been removed from the bedrock surface since then was, in fact, weathering rind, then the maximum possible thickness of rind that could have been developed during the postglacial period is equal to the sum of mean surface lowering $(5.5 \mathrm{~mm})$ and mean weathering rind thickness $(3.3 \mathrm{~mm})$. When viewed in this way, the maximum hypothetical penetration of microweathering processes at the bedrock surface ranges from 8-10 $\mathrm{mm}$ across all rock groups.

\section{Conclusions}

Investigations of microweathering have been undertaken on metamorphic, icescoured bedrock, on a high mountain plateau in Norway. Since the end of the Younger Dryas, bedrock microweathering has been slow and had little impact on landscape evolution in the Røldal area. Rates of microweathering obtained here are strikingly similar to those found in other periglacial and some temperate 
environments in comparable bedrock and suggest azonal controls on weathering processes. This is an indication that the control exerted by regional environmental and climatic characteristics on microweathering is subservient to bedrock lithology. The influence of local and micro-environmental factors on microweathering rates is difficult to determine because of the apparently conflicting role of variables, such as elevation and exposure, lichen cover, and snow burial.

The main factor controlling rates of microweathering is the mineralogical composition of bedrock, particularly the relative proportions of quartz and amphibolite.

Melanocratic and mesocratic bedrock containing high proportions of amphibolite and mica display greater weakening and surface lowering. Weathering rind is thin in these rocks and abundant striae are preserved despite surface lowering. Conversely, hololeucocratic and leucocratic bedrock display much less weakening and surface lowering, but display the thickest weathering rinds. Interestingly, evidence suggests that although the nature of microweathering differs according to lithology, the overall penetration depth is similar.

The use of multiple weathering indices has drawn attention to the relationships between in situ microweathering (surface weakening and rind formation) and microerosion (surface lowering). A concept is presented that models the cyclic interactions between these processes for two contrasting mineral assemblages.

This study demonstrates the important influence of rock properties, notably mineral composition, on postglacial microweathering in a periglacial environment. A similar level of rock control is likely to operate elsewhere where there are crystalline rocks and helps to explain the similarity in microweathering rates reported in the literature across broad environmental regions. These findings are consistent with contemporary views that factors other than temperature alone are of fundamental importance in weathering in cold environments. The results also demonstrate the relative inefficiency of microweathering as a force for landscape change during the postglacial period, but point to the need for further studies on the relationship between microweathering and macrodenudation.

\section{Acknowledgements}

Fieldwork was carried out during three MMU-LJMU Joint Norex Research Expeditions 2003-2006 and the author thanks student members for their invaluable field assistance. Grateful thanks are also due to Dr. Frank Nicholson for field assistance, helpful discussions, and invaluable support. I am also grateful to Dr. C. Philip Wheater and Penny A. Cook for use of their "FCStats V1.1h" software for conducting Dunn's analysis. I acknowledge the Norwegian Meteorological Office for the provision of regional climate data, and thank Nils and Helga Medhus for provision of local climate data. This work was partly funded by the Nuffield Foundation (Grant NAL/00698/G).

\section{References}

Anderson, B.G., 1980. The deglaciation of Norway after 10,000 B. P. Boreas 9, 211 216. 
André, M.-F., 1995. Postglacial microweathering of granite roche moutonnée in northern Scandinavia (Riksgränsen area, $68^{\circ} \mathrm{N}$ ). In: Slaymaker, O. (Ed.), Steepland Geomorphology. John Wiley, Chichester, UK, pp. 105-127.

André, M.-F., 1996a. Rock weathering rates in arctic and subarctic environments (Abisko Mts., Swedish Lappland). Zeitschrift für Geomorphologie 40(4), 499-517.

André, M.-F., 1996b. Vitesses de dissolution aréolaire postglaciare dans les karsts polaires et haut-alpins - de l'Arctique scandinave aux Alpes de Nouvelle-Guinée. Revue d'Analyse Spatiale Quantitative et Appliquée 38-39, 99-107.

André, M.-F., 2002. Rates of postglacial rock weathering on glacially scoured outcrops (Abisko-Riksgränsen area, $68^{\circ} \mathrm{N}$ ). Geografiska Annaler 84A(3-4), 139-150.

Aoyama, M., 2005. Rock glaciers in the northern Japanese Alps:

Palaeoenvironmental implications since the Late Glacial. Journal of Quaternary Science 20(5), 471-484.

Ballantyne, C.K., Black, N.M., Finlay, D.P., 1989. Enhanced boulder weathering under late-lying snowpatches. Earth Surface Processes and Landforms 14, 745-750.

Ballantyne, C.K., McCarroll, D., Nesje, A., Dahl, S.O., Stone, J.O., 1998. The last ice sheet in north-west Scotland: reconstruction and implications. Quaternary Science Reviews 17, 1149-1184.

Berrisford, M.S., 1991. Evidence for enhanced mechanical weathering associated with seasonally late-lying and perennial snow patches, Jotunheimen, Norway. Permafrost and Periglacial Processes 2(4), 331-340.

Beylich, A.A., Kolstrup, E., Thyrsted, T., Gintz, D., 2004. Water chemistry and its diversity in relation to local factors in the Latnjavagge drainage basin, arctic-oceanic Swedish Lapland. Geomorphology 58, 125-143.

Campbell, S.W., Thorn, C.E., Dixon, J.C., 2002. Spatial variation of early season surface water chemistry in Kärkevagge, Swedish Lapland. Geografiska Annaler 83A(4), 169-178.

Carter, N.E.A., Viles, H.A., 2004. Lichen hotspots: raised rock temperatures beneath Verrucaria negrescens on limestone. Geomorphology 62, 1-16.

Chen, J., Blume, H.P., Beyer, L., 2000. Weathering of rocks induced by lichen colonization - a review. Catena 39(2), 121-146.

Chinn, T.J.H, 1981. Use of rock weathering-rind thickness for Holocene absolute age-dating in New Zealand. Arctic and Alpine Research 13, 33-45.

Colman, S.M., Pierce, K.L., 1981. Weathering Rinds on Andesitic and Basaltic Stones as a Quaternary Age Indicator, Western United States. Geological Survey Professional Paper 1210. United States Government Printing Office, Washington DC, $54 \mathrm{pp}$. 
Dahl, R., 1967. Post-glacial micro-weathering of bedrock surfaces in the Narvik district of Norway. Geografiska Annaler 49A(2-4), 155-166.

Darmody, R.G., Thorn, C.E., Harder, R.L., Schlyter, J.P.L., Dixon, J.C., 2000.

Weathering implications of water chemistry in an arctic-alpine environment, northern Sweden. Geomorphology 34(1-2), 89-100.

Day, M.J., Goudie, A.S., 1977. Field assessment of rock hardness using the Schmidt hammer. BGRG Technical Bulletin 18, 19-29.

Dixon, J.C., Thorn, C.E., Darmody, R.G., Campbell, S.W., 2002. Weathering rinds and rock coatings from an Arctic alpine environment, northern Scandinavia.

Geological Society of America Bulletin 114(2), 226-238.

Dixon, J.C., Thorn, C.E., 2005. Chemical weathering and landscape development in mid-latitude alpine environments. Geomorphology 67, 127-145.

Dixon, J.C., Campbell, S.W., Thorn, C.E., Darmody, R.G., 2006. Incipient weathering rind development on introduced machine-polished granite discs in an Arctic alpine environment, northern Scandinavia. Earth Surface Processes and Landforms 31(1), 111-121.

Douglas, G.R., Whalley, W.B., McGreevy, J.P., 1991. Rock properties as controls on freeface debris fall activity. Permafrost and Periglacial Processes 2(4), 311-319.

Etienne, S., 2002. The role of biological weathering in periglacial areas: a study of weathering rinds in south Iceland. Geomorphology 47, 75-86.

Etienne, S., Dupont, J., 2002. Fungal weathering of basaltic rocks in a cold oceanic environment (Iceland): comparison between experimental and field observations. Earth Surface Processes 27, 737-748.

Gardner, J.S., 1969. Snowpatches; their influence on mountain wall temperatures and the geomorphic implications. Geografiska Annaler 51A, 114-120.

Glasser, N.F., Crawford, K.R., Hambrey, M.J., Bennett, M.R., Huddart, D., 1998. Lithological and structural controls on the surface wear characteristics of glaciated metamorphic bedrock surfaces: Ossian Sarsfjellet, Svalbard. The Journal of Geology 106, 319-329.

Gordon, S.J., Dorn, R.I., 2005. In situ weathering rind erosion. Geomorphology 67(12), 97-113.

Goudie, A.S., 2006. The Schmidt hammer in geomorphological research. Progress in Physical Geography 30(6), 703-718.

Hall, K., 1999. The role of thermal stress fatigue in the breakdown of rock in cold regions. Geomorphology 31, 47-63. 
Hall, K., André, M.-F., 2001. New insights into rock weathering from high-frequency rock temperature data: an Antarctic study of weathering by thermal stress.

Geomorphology 41, 23-35.

Hall, K., Thorn, C.E., Matsuoka, N., Prick, A., 2002. Weathering in cold regions:

Some thoughts and perspectives. Progress in Physical Geography 26(4), 577-603.

Ives, J.D., 1966. Blockfields, associated weathering forms on mountain tops and the nunatak hypothesis. Geografiska Annaler 48A, 220-223.

Jorde, K., 1977. Røldal 1314 I. Berggrunnsgeologisk M 1:50,000. Norges Geologiske Undersøkelse.

Matsukura, Y., 1994. A review of the studies on rock control in weathering processes. Transactions of the Japanese Geomorphological Union 15(3), 203-222.

Matsuoka, N., Thomachot, C.E., Oguchi, C.T., Hatta, T., Abe, M., Matsuzaki, H., 2006. Quaternary bedrock erosion and landscape evolution in the Sør Rondane Mountains, East Antarctica: Reevaluating rate and processes. Geomorphology 81, 408-420.

McGreevy, J.P., 1985. Thermal properties as controls on rock surface temperature maxima, and possible implications for rock weathering. Earth Surface Processes Landforms 10(2), 125-136.

Meybeck, M., 1987. Global chemical weathering of surficial rocks estimated from dissolved river loads. American Journal of Science 287, 401-428.

Naterstad, J., 1988. Haukelisæter 1414 IV. Berggrunnsgeologisk M 1:50,000. Norges Geologiske Undersøkelse.

Nicholson, D.T., 2001. Pore properties as indicators of breakdown mechanisms in experimentally weathered limestones. Earth Surface Processes and Landforms 26, 819-838.

Nicholson, D.T., in review. Holocene microweathering of ice-eroded bedrock, Røldal area, Hardangervidda, southern Norway. In: J. Knight (Ed), Periglacial and Paraglacial Landscapes. Geological Society Special Publication.

Nicholson, D.T., Nicholson, F.H., 2000. Physical deterioration of sedimentary rocks subjected to experimental freeze-thaw weathering. Earth Surface Processes and Landforms 25, 1295-1307.

Nyberg, R., 1991. Geomorphic processes at snowpatch sites in the Abisko mountains, northern Sweden. Zeitschrift für Geomorphologie 35(3), 321-343.

Oguchi, C.T., Matsukura, Y., 2000. Effect of porosity on the increase in weatheringrind thicknesses of andesite gravel. Engineering Geology 55(1-2), 77-89. 
Oguchi, C.T., Noda, T., Matsuoka, N., 2001. Weathering rind characteristics of blocky deposits in a deglaciated cirque on Mt. Yakushi, the Northern Japanese Alps. Annual Report of the Institute of Geoscience, University of Tsukuba 27, 17-23.

Olvmo, M., Johansson, M., 2002. The significance of rock structure, lithology and pre-glacial deep weathering for the shape of intermediate-scale glacial erosional landforms. Earth Surface Processes and Landforms 27, 251-268.

Owen, G., Matthews, J.A., Shakesby, R.A., 2006. Rapid Holocene chemical weathering on a calcitic lake shoreline in an Alpine periglacial environment: Attgloyma, Sognefjell, southern Norway. Permafrost and Periglacial Processes 17, 312.

Rae, A.C., Harrison, S., Mighall, T., Dawson, A.G., 2004. Periglacial trimlines and nunataks of the Last Glacial Maximum: the Gap of Dunloe, south-west Ireland. Journal of Quaternary Science 19, 87-97.

Rapp, A., 1960. Recent development of mountain slopes in Kärkevagge and surroundings, northern Scandinavia. Geografiska Annaler 42A, 65-200,

Selby, M.J., 1980. A rock mass strength classification for geomorphic purposes with tests from Antarctica and New Zealand. Zeitschrift fur Geomorphologie 24(1), 31-51.

Sumner, P., Nel, W., Holness, S., Boelhouwers, J., 2002. Rock weathering characteristics as relative-age indicators for glacial and post-glacial landforms on Marion Island. South African Geographical Journal 84(2), 153-157.

Thorn, C.E., 1975. Influence of late-lying snow on rock-weathering rinds. Arctic and Alpine Research 7(4), 373-378.

Thorn, C., Hall, K., 2002. Nivation and cryoplanation: the case for scrutiny and integration. Progress in Physical Geography 26(4), 533-550.

Thorp, P.W., 1981. An analysis of the spatial variability of glacial striae and friction cracks in part of the Western Grampians of Scotland. Quaternary Studies 1, 71-93.

Tuğrul, A., 1997. Change in pore size distribution due to weathering of basalts and its engineering significance. In: Marinos, P. G., Koukis, G. C., Tsiambaos, G. C. \& Stournara, G. C., (Eds). Engineering Geology and the Environment, Volume 1, Balkema, Rotterdam, pp. 419-424.

Yatsu, E., 1966. Rock Control in Geomorphology. Sozosha, Tokyo. 135p.

Yatsu, E., 1988. The Nature of Weathering: An Introduction. Sozosha, Tokyo. 624p. 


\section{Figure captions}

Fig. 1. Ice-scoured roches moutonnées at Rekkingeskara looking westward toward Valldalsvatnet.

Fig. 2. Location of study localities at Rekkingeskara, Snøskar, Middyrelva, Dyrskarnuten and Fjetlandsnuten and location of the Røldal area in Norway (inset).

Fig. 3. View southwestward across Rekkingeskara showing upstanding roches moutonnées within the broad distribution of blockstreams.

Fig. 4. Frequency distribution of bedrock surface lowering for each rock group.

Fig. 5. Box and whisker plot comparing postglacial bedrock surface lowering ( $\mathrm{mm} \mathrm{ka}^{-}$ $\left.{ }^{1}\right)$ for hololeucocratic $(H)$, leucocratic $(L)$, mesocratic $(M)$, and amphibolitic $(A)$ rocks. Extreme values are hidden. Boxes labelled with the same letter are not significantly different following Dunn's test for multiple comparisons.

Fig. 6. Box and whisker plots comparing Schmidt hammer rebound $R_{1}(\mathrm{~A})$ and $R_{2}(\mathrm{~B})$ for hololeucocratic $(H)$, leucocratic $(L)$, mesocratic $(M)$, and amphibolitic $(A)$ rocks. Boxes labelled with the same letter are not significantly different following Dunn's test for multiple comparisons.

Fig. 7. Box and whisker plot comparing surface weathering rind thickness $(\mathrm{mm})$ for hololeucocratic $(H)$, leucocratic $(L)$, mesocratic $(M)$, and amphibolitic $(A)$ rocks. Extreme values are hidden. Boxes labelled with the same letter are not significantly different following Dunn's test for multiple comparisons.

Fig. 8. Box and whisker plot comparing fracture wall weathering rind thickness $(\mathrm{mm})$ for hololeucocratic $(H)$, leucocratic $(L)$, mesocratic $(M)$, and amphibolitic $(A)$ rocks. Extreme values and outliers are hidden. Boxes labelled with the same letter are not significantly different following Dunn's test for multiple comparisons.

Fig. 9. Comparison of all microweathering indices against rock group $(H=$ hololeucocratic, $\mathrm{L}=$ leucocratic, $\mathrm{M}=$ mesocratic, and $\mathrm{A}=$ amphibolitic).

Fig. 10. Lithological-temporal model of bedrock microweathering for $(A)$ amphibolites and mica-rich rocks and (B) quartz-rich rocks. For explanation refer to text. 
Table 1

Rates of postglacial surface lowering

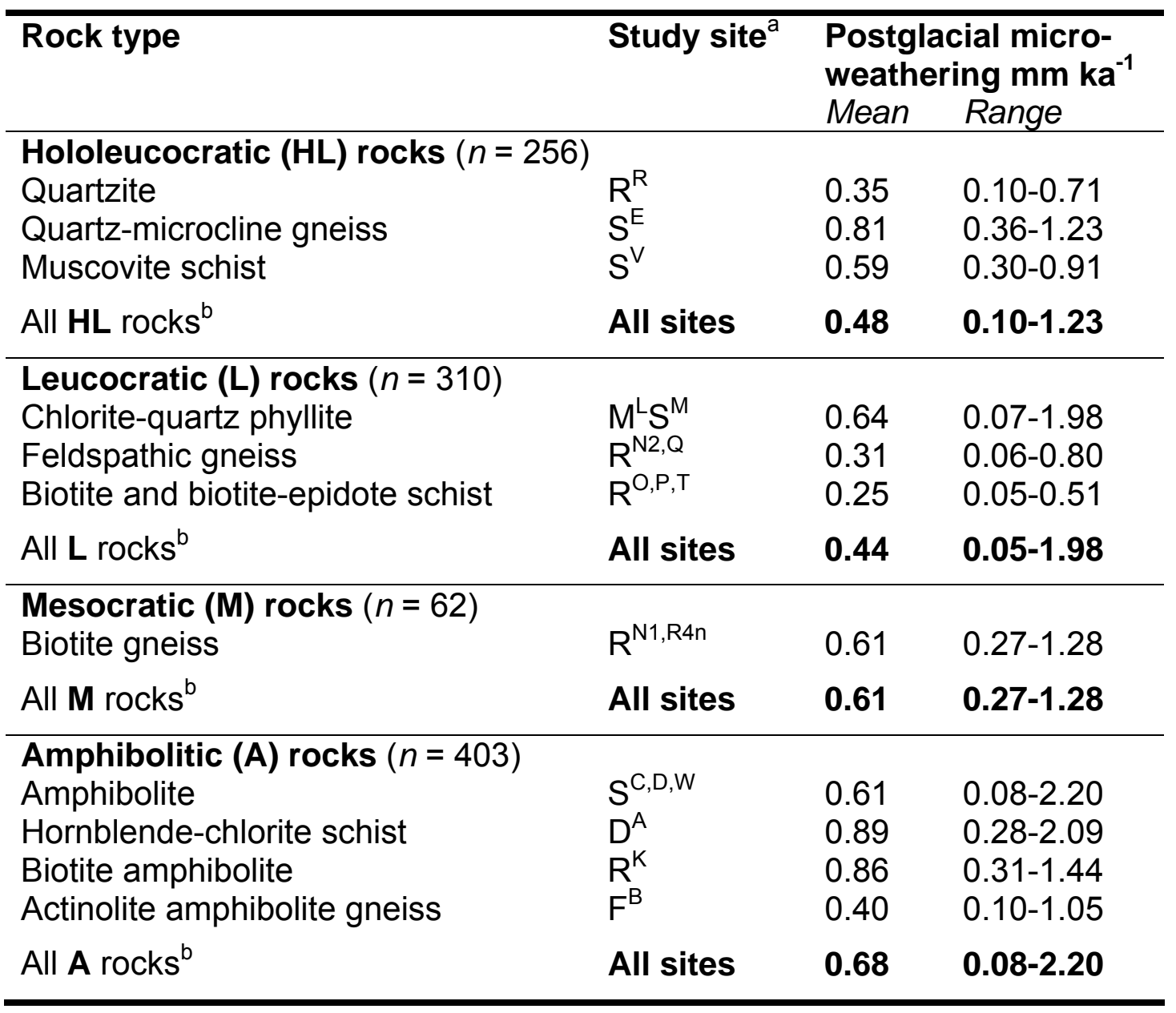

${ }^{a} \mathrm{R}=$ Rekkingeskara; $\mathrm{S}=$ Snøskar; $\mathrm{D}=$ Dyrskarnuten; $\mathrm{M}=$ Middyrelva; $\mathrm{F}=$ Fjetlandsnuten (refer to location map in Fig. 2). Superscripts refer to identities of roches moutonnées investigated.

${ }^{b}$ Mean and range of individual data points for all of the roches moutonnées in this rock group. 
Table 2

Mean rates of chemical erosion and surface lowering in cold environments

\begin{tabular}{|c|c|c|c|c|c|}
\hline Location & Method & $\begin{array}{l}\text { Surface } \\
\text { lowering } \\
\left(\mathrm{mm} \mathrm{ka}^{-1}\right)^{a}\end{array}$ & $\begin{array}{l}\text { Erosion } \\
\text { rate }^{\mathrm{b}} \\
\left(\mathrm{t} \mathrm{km}^{-2} \mathrm{a}^{-1}\right)\end{array}$ & Lithology & Source \\
\hline $\begin{array}{l}\text { Kärkevagge, } \\
\text { Sweden }\end{array}$ & $\begin{array}{l}\text { Solute } \\
\text { load }\end{array}$ & & $19.0-46.0$ & $\begin{array}{l}\text { Pyrite-rich granitic } \\
\text { schists }\end{array}$ & $\begin{array}{l}\text { Rapp (1960); } \\
\text { Darmody et al. } \\
\text { (2000); } \\
\text { Campbell et al. } \\
(2002)\end{array}$ \\
\hline $\begin{array}{l}\text { Latnjavagge, } \\
\text { Sweden }\end{array}$ & $\begin{array}{l}\text { Solute } \\
\text { load }\end{array}$ & & 5.4 & Micaschist & $\begin{array}{l}\text { Beylich et al. } \\
(2004)\end{array}$ \\
\hline \multirow{3}{*}{$\begin{array}{l}\text { Abisko- } \\
\text { Riksgränsen, } \\
\text { Sweden }\end{array}$} & Surface & 0.5 & $\underline{1.3}$ & Amphibolite & André (1995, \\
\hline & lowering & $(0.2-1.2)$ & $(0.5-3.2)$ & $\begin{array}{l}\text { Biotite-rich granite } \\
\text { and syenite }\end{array}$ & 1996a, b, 2002) \\
\hline & & 5.4 & 14.3 & $\begin{array}{l}\text { Carbonate } \\
\text { sedimentary rocks }\end{array}$ & \\
\hline $\begin{array}{l}\text { Narvik, north } \\
\text { Norway }\end{array}$ & $\begin{array}{l}\text { Surface } \\
\text { lowering }\end{array}$ & 1.0 & & Granite & Dahl (1967) \\
\hline $\begin{array}{l}\text { Sognjefjell, south- } \\
\text { west Norway }\end{array}$ & $\begin{array}{l}\text { Solute } \\
\text { load }\end{array}$ & 15.5 & & Calcitic schists & $\begin{array}{l}\text { Owen et al. } \\
(2006)\end{array}$ \\
\hline Global & $\begin{array}{l}\text { Solute } \\
\text { load }\end{array}$ & & $18.0-19.0$ & Crystalline rocks & Meybeck (1987) \\
\hline $\begin{array}{l}\text { Snøskar, southern } \\
\text { Norway }\end{array}$ & $\begin{array}{l}\text { Solute } \\
\text { load }\end{array}$ & & 4.9 & $\begin{array}{l}\text { Feldspathic schists, } \\
\text { biotite-rich schist } \\
\text { and amphibolite }\end{array}$ & $\begin{array}{l}\text { Nicholson (in } \\
\text { review) }\end{array}$ \\
\hline Røldal, Norway & $\begin{array}{l}\text { Surface } \\
\text { lowering }\end{array}$ & $\begin{array}{l}0.55 \\
(0.05-2.2)\end{array}$ & $\frac{1.5}{(0.3-5.8)}$ & $\begin{array}{l}\text { Feldspathic schists, } \\
\text { biotite-rich schist } \\
\text { and amphibolite }\end{array}$ & $\begin{array}{l}\text { Nicholson, this } \\
\text { paper }\end{array}$ \\
\hline
\end{tabular}

${ }^{\text {a }}$ Values in parentheses are ranges and other values are means.

${ }^{b}$ Values underlined are erosion rates $\left(\mathrm{t} \mathrm{km}^{-2} \mathrm{a}^{-1}\right)$ calculated from direct measurement of surface lowering $\left(\mathrm{mm} \mathrm{ka}^{-1}\right)$. 
Table 3

Striation morphometry

\begin{tabular}{|c|c|c|c|c|c|}
\hline \multirow[t]{3}{*}{ Rock type } & \multirow{3}{*}{$\begin{array}{l}\text { Study } \\
\text { site }^{a}\end{array}$} & \multicolumn{4}{|c|}{ Glacial striation morphometry } \\
\hline & & \multicolumn{2}{|c|}{ Width (mm) } & \multicolumn{2}{|c|}{ Depth (mm) } \\
\hline & & Mean & Range & Mean & Range \\
\hline \multicolumn{6}{|c|}{ Hololeucocratic $(\mathrm{HL})$ rocks $(n=43)$} \\
\hline Quartzite & $\mathrm{R}^{\mathrm{R}^{\prime}}$ & 221.5 & $2-500$ & 42.1 & $0.2-80$ \\
\hline Quartzo-feldspathic schist & $S^{E}$ & 12.0 & $12-12$ & 1.1 & $1.1-1.1$ \\
\hline Muscovite schist & $S^{F, V}$ & 33.3 & $20-300$ & 7.1 & $2.5-100$ \\
\hline All HL rocks ${ }^{b}$ & All sites & 105.2 & $2-500$ & 20.3 & $0.2-100$ \\
\hline \multicolumn{6}{|l|}{ Leucocratic $(\mathrm{L})$ rocks $(n=20)$} \\
\hline Chlorite mica schist & $S^{M}$ & 15.0 & $15-15$ & 2.5 & $2.0-3.0$ \\
\hline Feldspathic gneiss & $R^{J}$ & 48.7 & $8-130$ & 4.7 & 1.0.2.0 \\
\hline Biotite and biotite-epidote schist & $R^{O, P, T}$ & 66.7 & $3-450$ & 9.6 & $1.0-80$ \\
\hline All $L$ rocks ${ }^{b}$ & All sites & 51.1 & $3-450$ & 7.1 & $1.0-80$ \\
\hline \multicolumn{6}{|l|}{ Mesocratic $(\mathrm{M})$ rocks $(n=27)$} \\
\hline Biotite gneiss & $\mathrm{R}^{\mathrm{N} 1, \mathrm{R} 4 \mathrm{n}}$ & 32.7 & $4-50$ & 2.2 & $1.0-13$ \\
\hline All $\mathbf{M}$ rocks $^{\mathrm{b}}$ & All sites & 32.7 & 4-50 & 2.2 & $1.0-13$ \\
\hline \multicolumn{6}{|c|}{ Amphibolitic $(\mathrm{A})$ rocks $(n=283)$} \\
\hline Amphibolite & $S^{C, D, W}$ & 68.1 & $3-400$ & 12.3 & $0.5-200$ \\
\hline Hornblende-chlorite schist & $D^{A}$ & 68.9 & $7-500$ & 5.8 & $1.0-70$ \\
\hline Biotite amphibolite & $\mathrm{R}^{\mathrm{K}, \mathrm{R} 4 \mathrm{~s}}$ & 43.1 & $2-200$ & 6.9 & $0.4-40$ \\
\hline Actinolite amphibolite gneiss & $F^{B}$ & 1.3 & $0.2-4$ & 2.1 & $1.0-5.0$ \\
\hline All $A$ rocks $^{b}$ & All sites & 48.9 & $2-500$ & 6.7 & $0.4-200$ \\
\hline
\end{tabular}

${ }^{\mathrm{a}} \mathrm{R}=$ Rekkingeskara; $\mathrm{S}=$ Snøskar; $\mathrm{D}=$ Dyrskarnuten; $\mathrm{M}=$ Middyrelva; $\mathrm{F}=$ Fjetlandsnuten (refer to location map in Fig. 2). Superscripts refer to identities of roches moutonnées investigated.

${ }^{b}$ Mean and range of individual data points for all of the roches moutonnées in this rock group. 
Table 4

Surface hardness from Schmidt hammer rebound

\begin{tabular}{|c|c|c|c|c|c|}
\hline Rock type & $\begin{array}{l}\text { Study } \\
\text { site }^{a}\end{array}$ & \multicolumn{4}{|c|}{$\begin{array}{l}\text { Surface hardness (Schmidt } \\
\text { hammer rebound) }\end{array}$} \\
\hline \multicolumn{6}{|c|}{ Hololeucocratic $(\mathrm{HL})$ rocks $(n=460)$} \\
\hline Quartzite & $\mathrm{R}^{\mathrm{R}}$ & 60.4 & $36.4-75.0$ & 68.1 & $53.5-77.2$ \\
\hline Quartzo-feldspathic schist & $S^{E}$ & 58.1 & $32.1-70.7$ & 67.1 & $55.7-72.9$ \\
\hline Muscovite schist & $S^{V}$ & 61.5 & $53.4-66.3$ & 67.7 & 64.2-71.7 \\
\hline All HL rocks ${ }^{b}$ & All sites & 59.8 & 53.6-65.6 & 67.8 & 63.9-71.2 \\
\hline \multicolumn{6}{|c|}{ Leucocratic $(\mathrm{L})$ rocks $(n=858)$} \\
\hline Chlorite mica schist & $M^{L} S^{M}$ & 61.4 & $36.2-77.2$ & 67.7 & 47.1-79.3 \\
\hline Feldspathic gneiss & $\mathrm{R}^{\mathrm{J}, \mathrm{N} 2, \mathrm{Q}}$ & 53.5 & $24.6-67.7$ & 65.6 & 38.5-76.1 \\
\hline Biotite and biotite-epidote schist & $\mathrm{R}^{\mathrm{H}, \mathrm{O}, \mathrm{P}, \mathrm{T}, \mathrm{U}}$ & 56.1 & $30.1-73.0$ & 65.2 & $36.2-76.1$ \\
\hline All $\mathbf{L}$ rocks ${ }^{b}$ & All sites & 57.1 & 40.3-70.6 & 65.8 & 57.7-73.1 \\
\hline \multicolumn{6}{|l|}{ Mesocratic $(\mathrm{M})$ rocks $(n=100)$} \\
\hline Biotite gneiss & $\mathrm{R}^{\mathrm{N} 1, \mathrm{R} 4 \mathrm{n}}$ & 50.9 & $50.2-51.6$ & 62.0 & $59.9-64.0$ \\
\hline All $\mathbf{M}$ rocks $^{b}$ & All sites & 50.9 & $50.2-51.6$ & 62.0 & $59.9-64.0$ \\
\hline \multicolumn{6}{|c|}{ Amphibolitic $(\mathrm{A})$ rocks $(n=600)$} \\
\hline Amphibolite & $S^{C, D, W}$ & 46.5 & $17.7-64.3$ & 59.5 & 36.4-68.9 \\
\hline Hornblende-chlorite schist & $\mathrm{D}^{\mathrm{A}}$ & 43.8 & $27.5-54.5$ & 59.4 & 53.4-67.4 \\
\hline Biotite amphibolite & $\mathrm{R}^{\mathrm{K}, \mathrm{R} 4 \mathrm{~s}}$ & 44.1 & $25.7-62.0$ & 60.5 & 46.0-70.7 \\
\hline Actinolite amphibolite gneiss & $F^{\mathrm{B}}$ & 47.3 & $34.1-64.3$ & 60.2 & $49.2-68.6$ \\
\hline All A rocks $^{\mathrm{b}}$ & All sites & 45.6 & 37.8-52.2 & 59.7 & 54.9-62.7 \\
\hline
\end{tabular}

${ }^{\mathrm{a}} \mathrm{R}=$ Rekkingeskara; $\mathrm{S}=$ Snøskar; $\mathrm{D}=$ Dyrskarnuten; $\mathrm{M}=$ Middyrelva; $\mathrm{F}=$ Fjetlandsnuten (refer to location map in Fig. 2). Superscripts refer to identities of roches moutonnées investigated.

${ }^{\mathrm{b}}$ Mean and range of roches moutonnées mean values. 
Table 5

Weathering rind thickness on exposed surfaces and fracture walls

\begin{tabular}{|c|c|c|c|c|c|}
\hline \multirow[t]{3}{*}{ Rock type } & \multirow{3}{*}{$\begin{array}{l}\text { Study } \\
\text { site }^{a}\end{array}$} & \multicolumn{4}{|c|}{ Weathering rind thickness (mm) } \\
\hline & & \multicolumn{2}{|c|}{ Exposed bedrock } & \multicolumn{2}{|c|}{ Fracture walls } \\
\hline & & Mean & Range & Mean & Range \\
\hline \multicolumn{6}{|c|}{ Hololeucocratic $(\mathrm{HL})$ rocks $(n=126,30)^{b}$} \\
\hline Quartzite & $\mathrm{R}^{\mathrm{R}}$ & 3.9 & $0.7-7.0$ & 4.9 & $0.5-20.7$ \\
\hline Quartzo-feldspathic schist & $S^{E}$ & 4.5 & $1.5-8.6$ & 4.1 & $0.2-11.1$ \\
\hline Muscovite schist & $S^{F, V}$ & 7.0 & $1.1-26.2$ & 1.5 & $0.2-3.1$ \\
\hline All HL rocks ${ }^{c}$ & All sites & 5.0 & $0.7-26.2$ & 4.3 & $0.2-20.7$ \\
\hline \multicolumn{6}{|c|}{ Leucocratic $(\mathrm{L})$ rocks $(n=186,52)^{\mathrm{b}}$} \\
\hline Chlorite mica schist & $\mathrm{M}^{\mathrm{L}} \mathrm{S}^{\mathrm{M}}$ & 4.6 & $0.8-12.0$ & 1.3 & $0.1-4.9$ \\
\hline Feldspathic gneiss & $\mathrm{R}^{\mathrm{J}, \mathrm{N} 2, \mathrm{Q}}$ & 2.5 & $0.1-12.0$ & 3.9 & $0.8-15.1$ \\
\hline Biotite and biotite-epidote schist & $\mathrm{R}^{\mathrm{H}, \mathrm{O}, \mathrm{P}, \mathrm{T}, \mathrm{U}}$ & 3.2 & $0.4-13.0$ & 1.7 & $0.1-9.6$ \\
\hline All L rocks ${ }^{c}$ & All sites & 3.3 & 0.1-13.0 & 2.2 & 0.1-15.1 \\
\hline \multicolumn{6}{|c|}{ Mesocratic (M) rocks $(n=29,18)^{b}$} \\
\hline Biotite gneiss & $\mathrm{R}^{\mathrm{N} 1, \mathrm{R} 4 \mathrm{n}}$ & 1.9 & $0.1-5.2$ & 1.3 & $0.1-9.5$ \\
\hline All $M$ rocks $^{c}$ & All sites & 1.9 & $0.1-5.2$ & 1.3 & 0.1-9.5 \\
\hline \multicolumn{6}{|c|}{ Amphibolitic $(\mathrm{A})$ rocks $(n=186,42)^{\mathrm{b}}$} \\
\hline Amphibolite & $S^{C, D, W}$ & 1.9 & $0.2-7.0$ & 1.4 & $0.2-5.1$ \\
\hline Hornblende-chlorite schist & $D^{A}$ & 2.9 & $0.4-7.8$ & 3.1 & $1.0-5.6$ \\
\hline Biotite amphibolite & $\mathrm{R}^{\mathrm{K}, \mathrm{R} 4 \mathrm{~s}}$ & 1.5 & $0.3-3.4$ & 1.0 & $0.1-2.3$ \\
\hline Actinolite amphibolite gneiss & $\mathrm{F}^{\mathrm{B}}$ & 3.6 & $0.9-8.9$ & 2.2 & $0.3-9.2$ \\
\hline All $A$ rocks ${ }^{c}$ & All sites & 2.4 & $0.2-8.9$ & 1.7 & 0.1-9.2 \\
\hline
\end{tabular}

${ }^{\mathrm{a}} \mathrm{R}=$ Rekkingeskara; $\mathrm{S}=$ Snøskar; $\mathrm{D}=$ Dyrskarnuten; $\mathrm{M}=$ Middyrelva; $\mathrm{F}=$ Fjetlandsnuten (refer to location map in Fig. 2). Superscripts refer to identities of roches moutonnées investigated.

${ }^{\mathrm{b}}$ Exposed bedrock, fracture walls.

${ }^{\mathrm{c}}$ Mean and range of individual data points for all of the roches moutonnées in this rock group. 


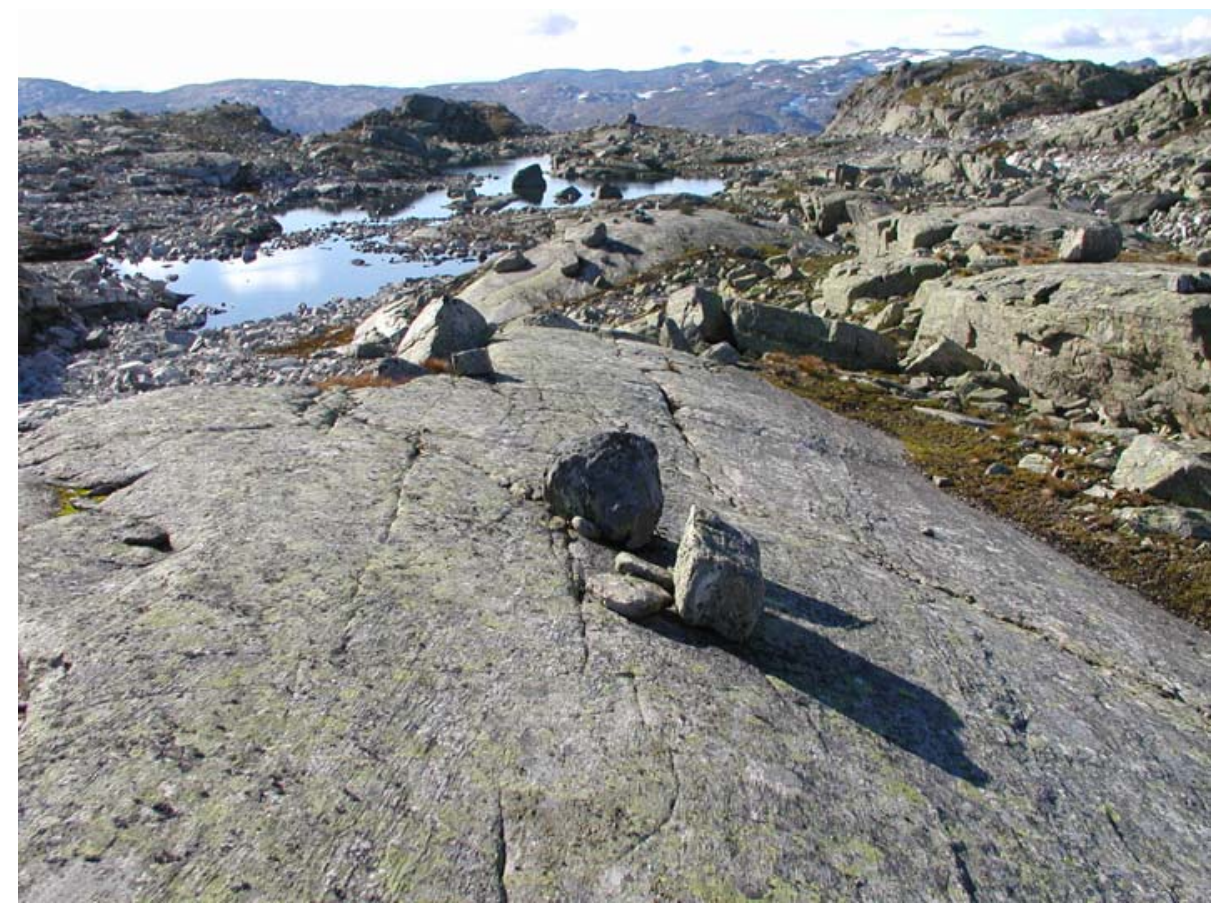

Figure 1: Ice-scoured roches moutonnées at Rekkingeskara looking westward toward Valldalsvatnet. 


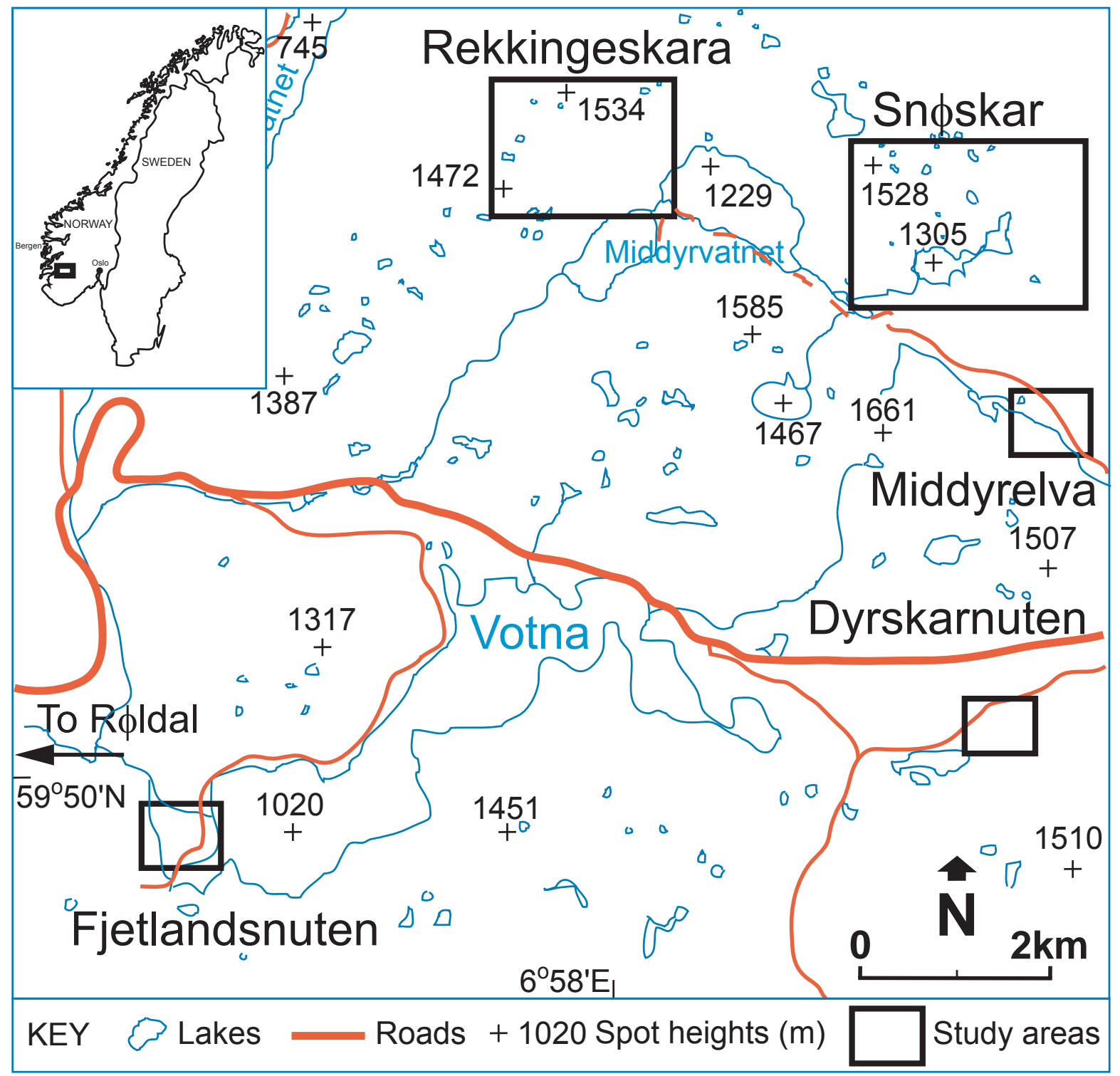

Figure 2: Location of study localities at Rekkingeskara, Snøskar, Middyrelva, Dyrskarnuten and Fjetlandsnuten and location of the Røldal area in Norway (inset) 


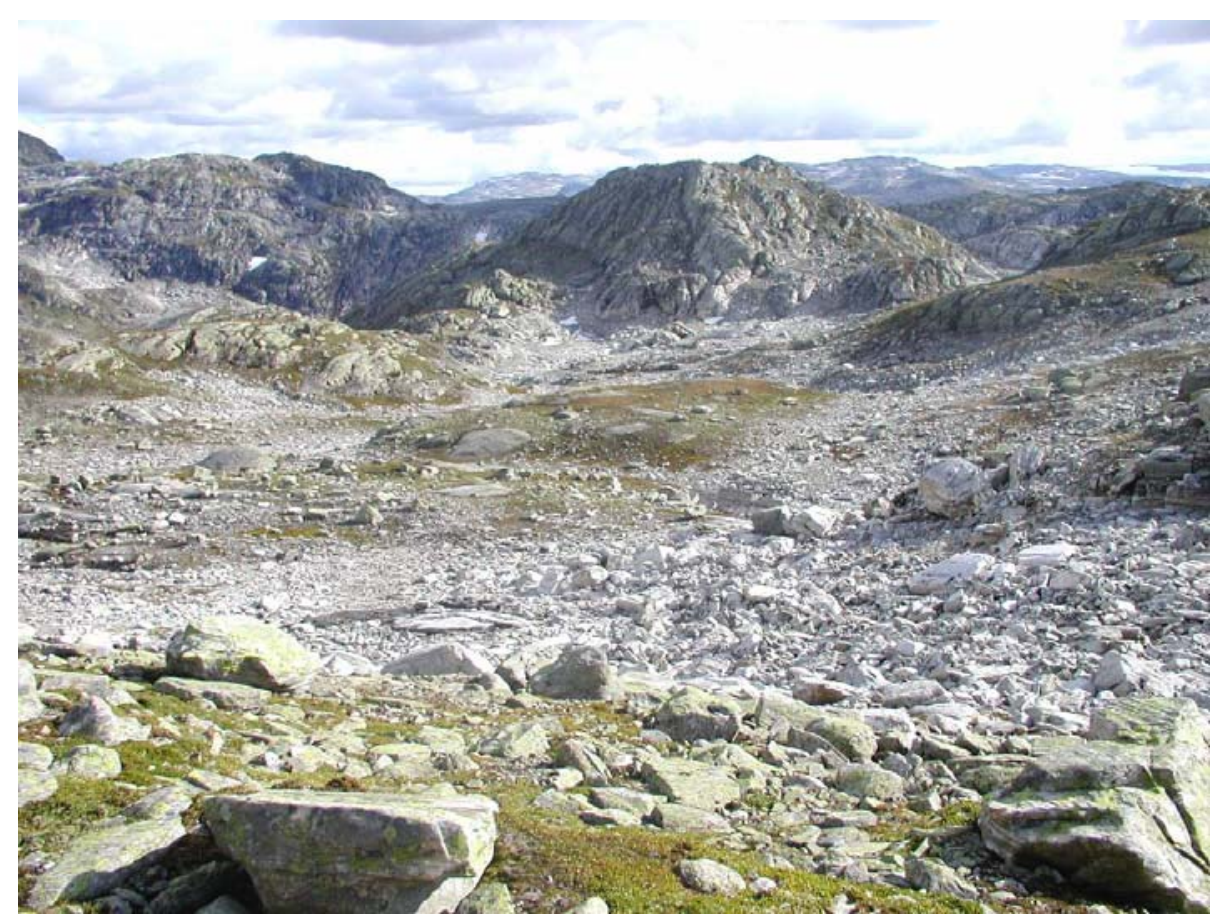

Figure 3: View southwestward across Rekkingeskara showing upstanding roches moutonnées within the broad distribution of blockstreams. 


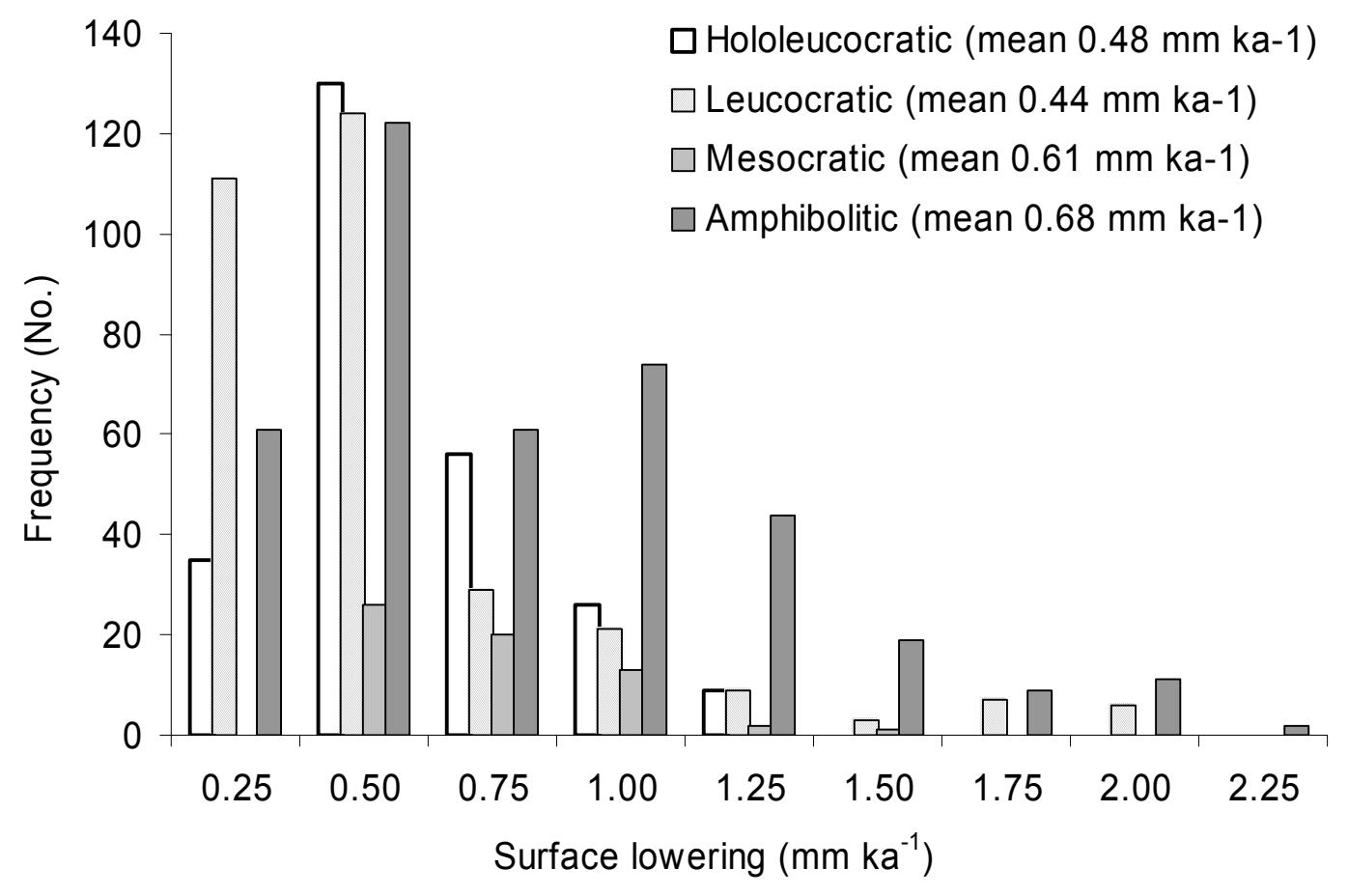

Figure 4: Frequency distribution of bedrock surface lowering for each rock group.

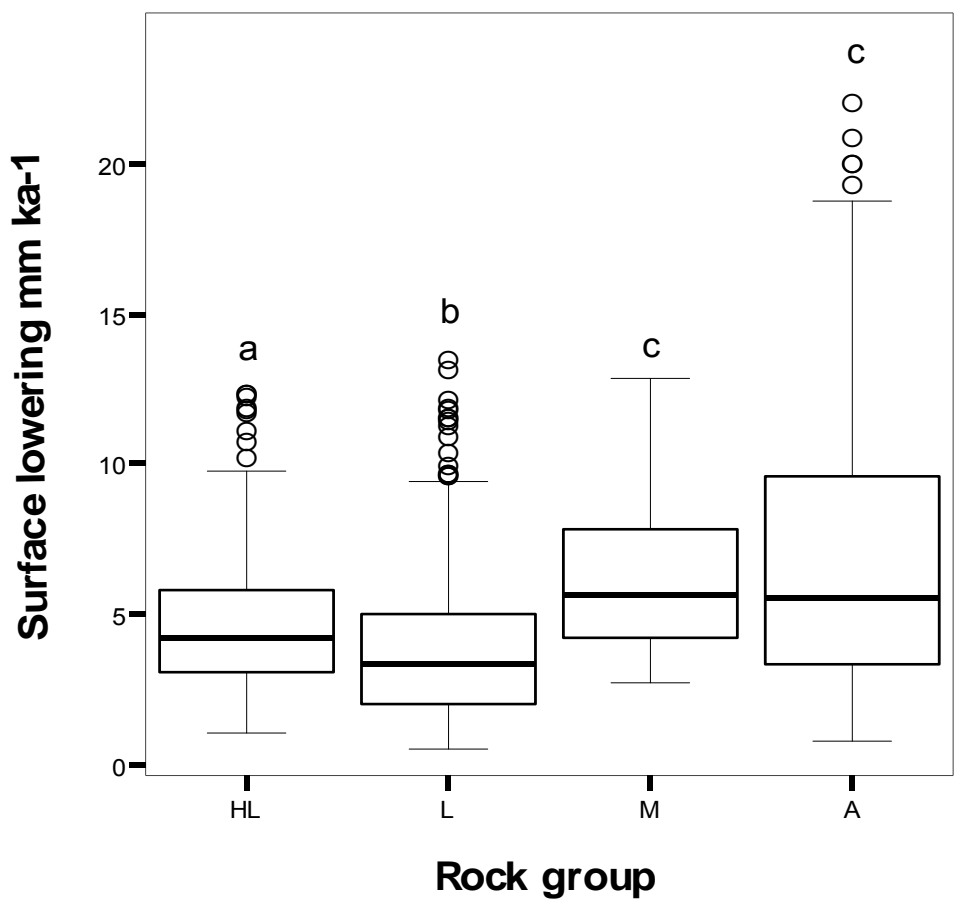

Figure 5: Box and whisker plot comparing postglacial bedrock surface lowering $(\mathrm{mm}$ $\mathrm{ka}^{-1}$ ) for hololeucocratic $(\mathrm{H})$, leucocratic $(\mathrm{L})$, mesocratic $(\mathrm{M})$, and amphibolitic $(A)$ rocks. Extreme values are hidden. Boxes labelled with the same letter are not significantly different following Dunn's test for multiple comparisons. 
A)

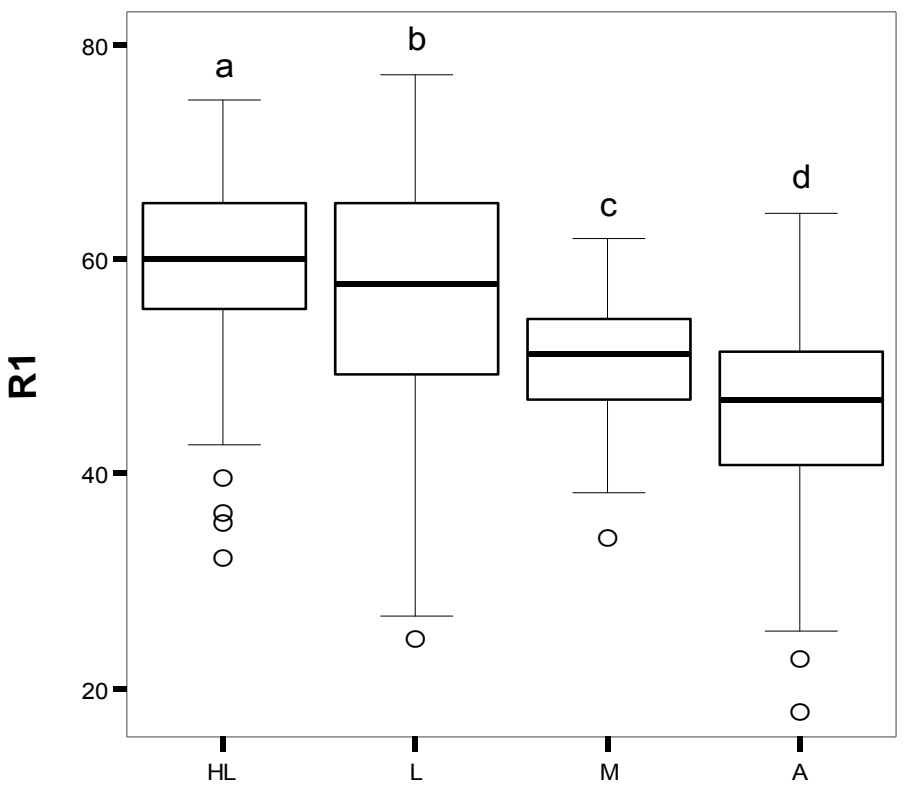

Rock group

B)

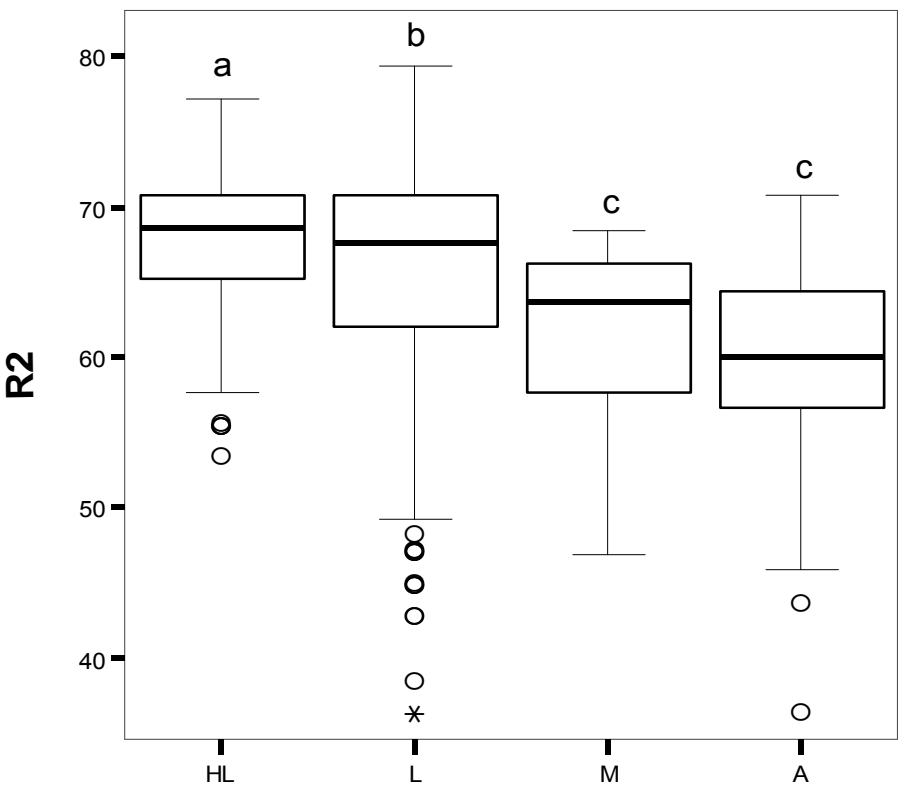

Rock group

Figure 6: Box and whisker plots comparing Schmidt hammer rebound $R_{1}(A)$ and $R_{2}$ $(B)$ for hololeucocratic $(H)$, leucocratic $(L)$, mesocratic $(M)$, and amphibolitic $(A)$ rocks. Boxes labelled with the same letter are not significantly different following Dunn's test for multiple comparisons. 


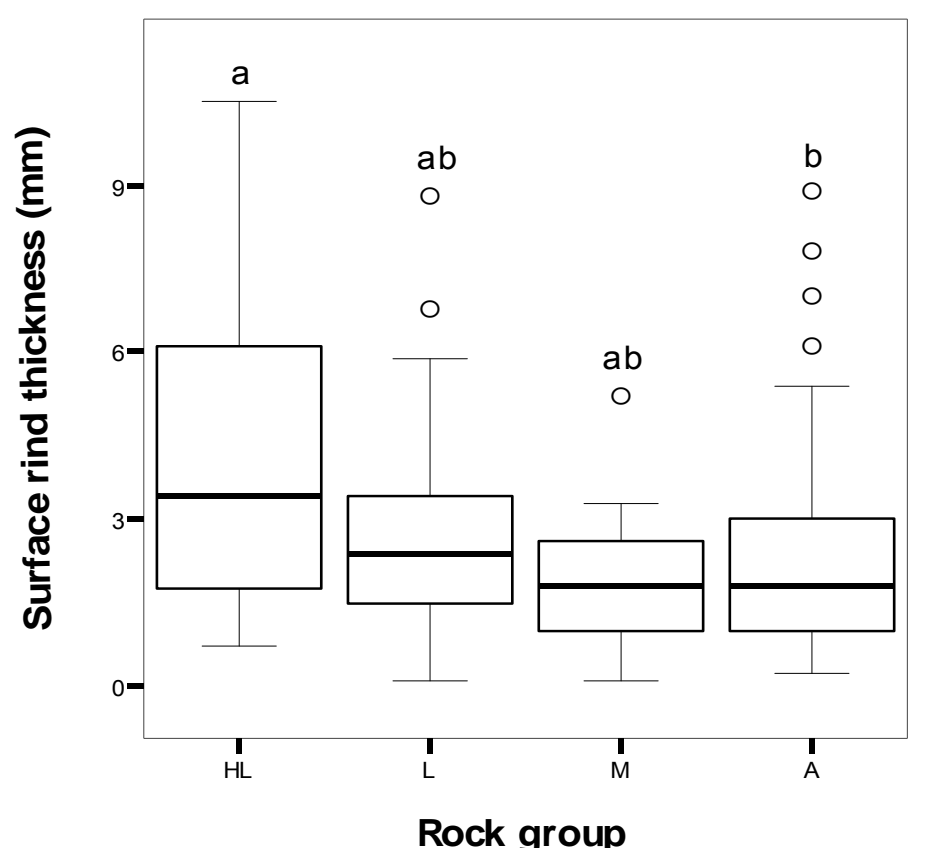

Figure 7: Box and whisker plot comparing surface weathering rind thickness (mm) for hololeucocratic $(H)$, leucocratic $(L)$, mesocratic $(M)$, and amphibolitic $(A)$ rocks. Extreme values are hidden. Boxes labelled with the same letter are not significantly different following Dunn's test for multiple comparisons.

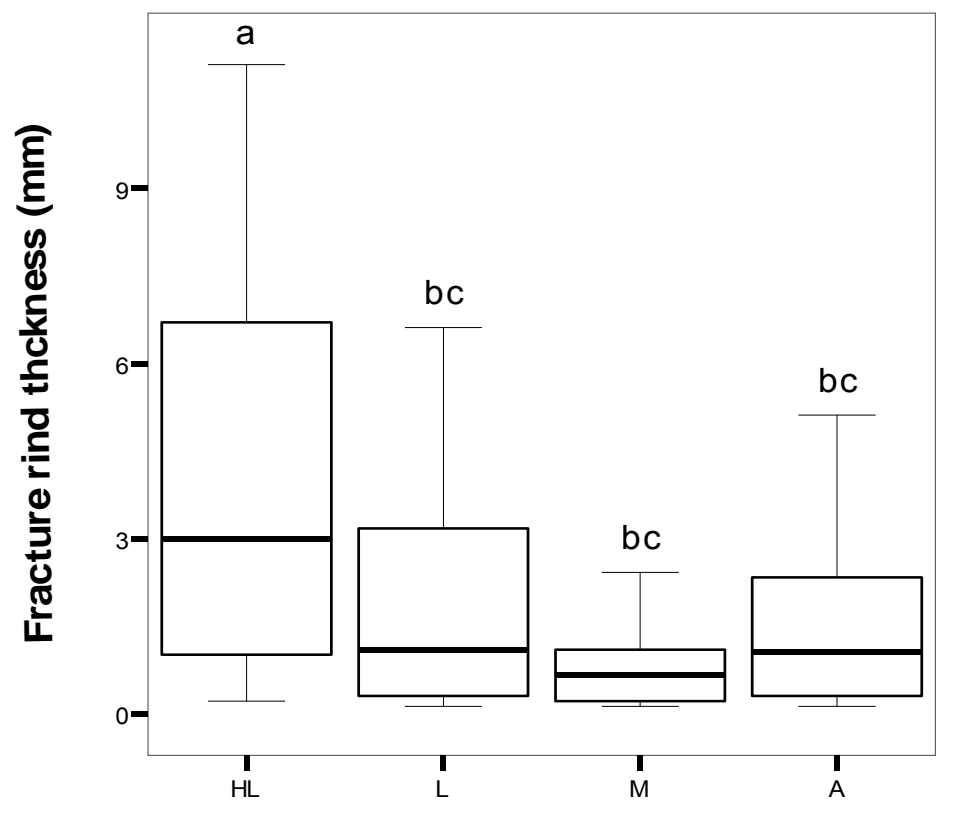

Rock group

Figure 8: Box and whisker plot comparing fracture wall weathering rind thickness $(\mathrm{mm})$ for hololeucocratic $(\mathrm{H})$, leucocratic $(\mathrm{L})$, mesocratic $(\mathrm{M})$, and amphibolitic $(\mathrm{A})$ rocks. Extreme values and outliers are hidden. Boxes labelled with the same letter are not significantly different following Dunn's test for multiple comparisons. 

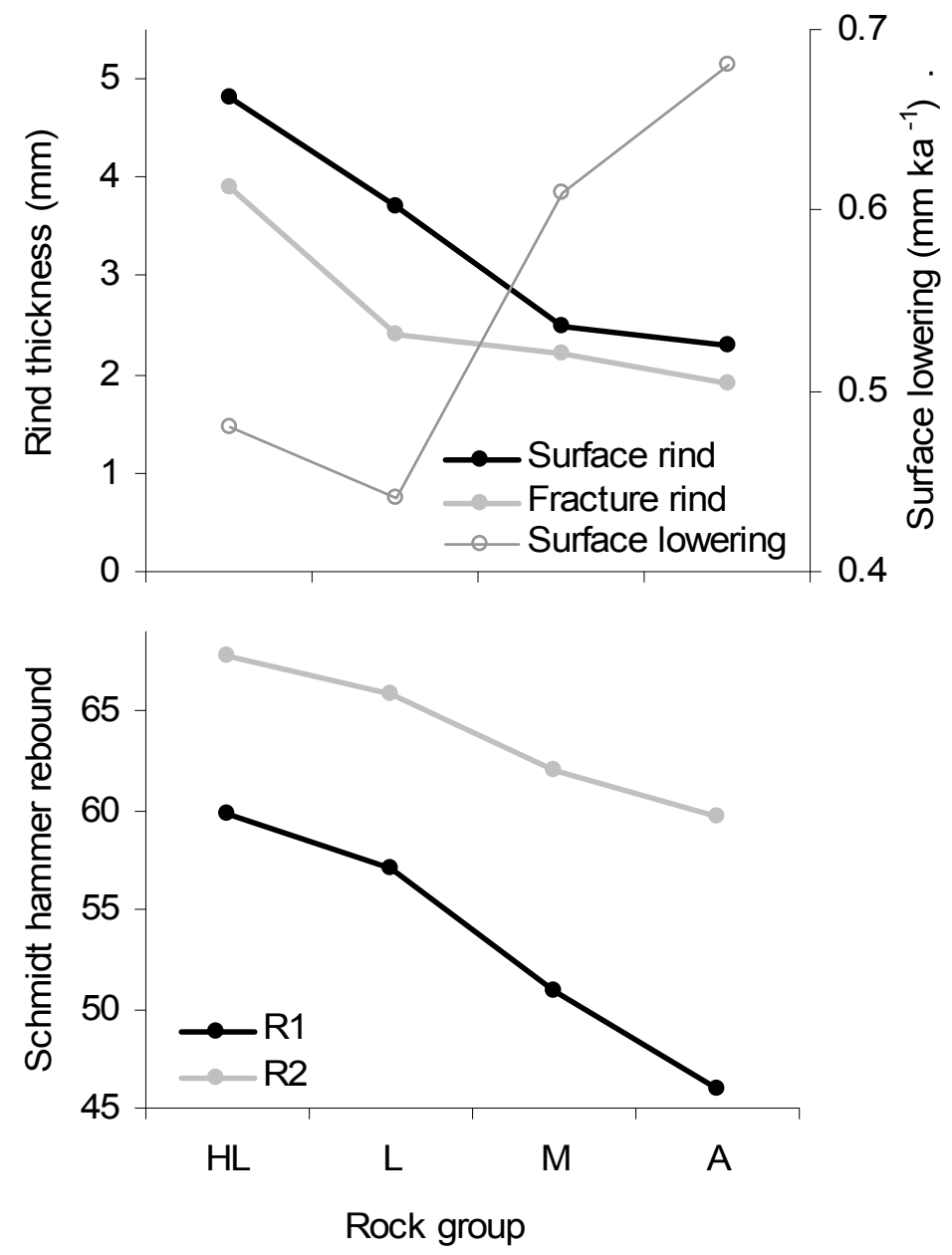

Figure 9: Comparison of all microweathering indices against rock group $(\mathrm{H}=$ hololeucocratic, $\mathrm{L}=$ leucocratic, $\mathrm{M}=$ mesocratic, and $\mathrm{A}=$ amphibolitic). 
A)
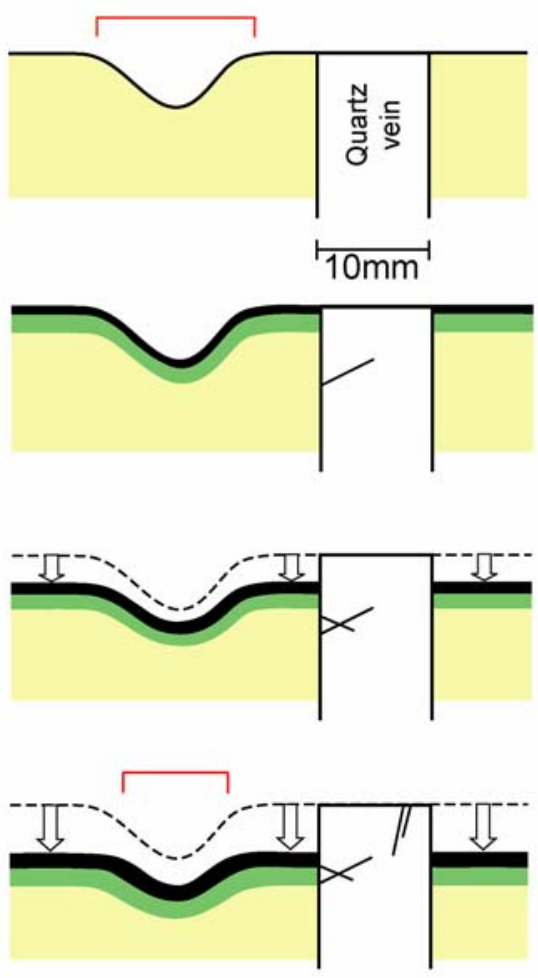

B)

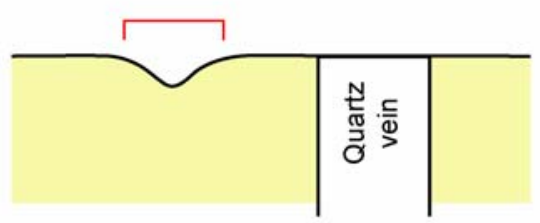

Phase

I

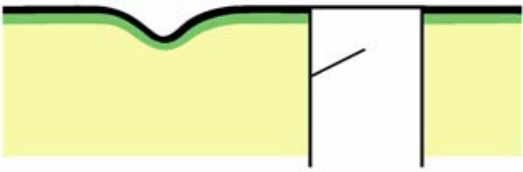

II

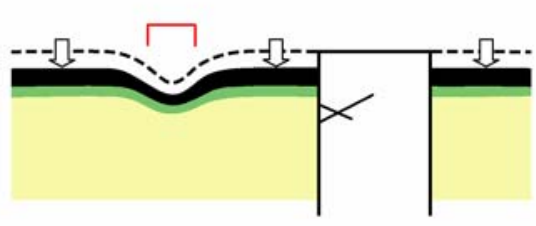

III

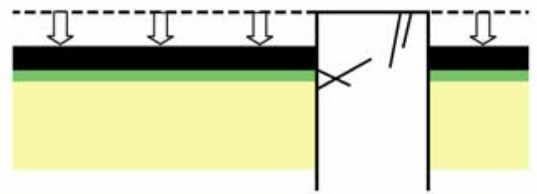

IV

Weathering rind

Zone of weakening

Fresh, unweathered bedrock

Figure 10: Lithological-temporal model of bedrock microweathering for (A) amphibolites and mica-rich rocks and (B) quartz-rich rocks. For explanation refer to text. 